Przegląd Narodowościowy / Review of Nationalities • nr 7/2017 • World of Slavs / Świat Słowian

\title{
Report from a nationwide scientific conference "The religious conditioning of politics / political determinants of religion", Łagów, 1-3.06.2017
}

\author{
Sprawozdanie z ogólnopolskiej konferencji naukowej „Religijne \\ uwarunkowania polityki / polityczne uwarunkowania religii", Łagów, 1-3.06.2017 r.
}

Organized by the Institute of Political Science of the University of Zielona Góra the nationwide scientific conference "Religious conditioning of politics. The political conditioning of religion" was a response to the needs of the scientific community for a substantive discussion of the importance of political science of religion as a sub-discipline of the political science. The conference also fits in the context of several other scientific meetings this year (including the ones at the Cardinal Stefan Wyszyński University in Warsaw and Maria Curie Skłodowska University in Lublin). The organizational committee was composed of: Dr. hab. Ryszard Michalak, prof. UZ (scientific director of the conference), Dr. hab. Wioletta Husar, MA Daria Podedworna, MA Weronika Górnicka (secretaries of the conference), Dr. Piotr Pochyły, Martyna Masłowska, MA, and Piotr Filipowski MA, (members of the committee).

Taking place on 1-3 June 2017 in Łagów (Swiebodzin County), the deliberations created the conditions for a multi-level analysis of the interdependence between
Zorganizowana przez Instytut Politologii Uniwersytetu Zielonogórskiego ogólnopolska konferencja naukowa „Religijne uwarunkowania polityki. Polityczne uwarunkowania religii" była odpowiedzią na zapotrzebowanie środowiska naukowego na merytoryczną dyskusję o znaczeniu politologii religii jako subdyscypliny nauk o polityce. Konferencja wpisana była jednocześnie w kontekst kilku innych tegorocznych spotkań naukowych (m.in. na Uniwersytecie Kardynała Stefana Wyszyńskiego w Warszawie i na Uniwersytecie Marii Curie Skłodowskiej w Lublinie). W skład komitetu organizacyjnego weszli: dr hab. Ryszard Michalak, prof. UZ (kierownik naukowy konferencji), dr hab. Łukasz Młyńczyk (kierownik organizacyjny konferencji), mgr Wioletta Husar, mgr Daria Podedworna, mgr Weronika Górnicka (sekretarze konferencji), dr Piotr Pochyły, mgr Martyna Masłowska oraz płk mgr Piotr Filipowski (członkowie komitetu).

Odbywające się w dniach 1-3 czerwca 2017 r. w Łagowie (pow. świebodziński) obrady stworzyły warunki dla wielopo-

* Correspondence address: Instytut Politologii, Uniwersytet Zielonogórski, Al. Wojska Polskiego, 69 65-762 Zielona Góra, Polska, e-mail: weronikagornicka@wp.pl. 
politics and religion. The main focus of the conference included topics such as conceptualisation in the field of political science of religion, methodological issues related to the politics of religion as subdisciplines of political science and subdisciplines of religion, religious factors in political studies and political factors in religious studies, politics and politics of religious narratives, As a part of public policy, religion in the institutional and systemic dimension, religion in the context of international and geopolitical, or social phenomena determined by religious factors and religious phenomena determined by political factors.

The conference was attended by representatives of sixteen universities: University of Warsaw, Maria Curie-Skłodowska University in Lublin, Cardinal Stefan Wyszyński University in Warsaw, Nicolaus Copernicus University in Toruń, University of Opole, University of Łódź, University of Economics in Cracow, University of Technology and Humanities in Radom, Academy of Ignatianum in Cracow, Pomeranian Academy in Slupsk, Jakub from Paradyza in Gorzow Wlkp., The Higher School of Democracy in Grudziadz and the Military Academy of Technology in Warsaw. Societies and organizations were also represented, among others: Congress of Conservative Women, Association of Europe of the Future, Plock Scientific Society and Agape Publishing House. ziomowej analizy wzajemnych zależności pomiędzy polityką a religią. W centrum zainteresowania uczestników konferencji znalazły się takie zagadnienia jak: konceptualizacja w obszarze politologii religii, kwestie metodologiczne dotyczące politologii religii jako subdyscypliny politologii oraz subdyscypliny religioznawstwa, czynnik religijny w badaniach politologicznych oraz czynnik polityczny w badaniach religioznawczych, polityzacja i polityczność narracji religijnej, problemy polityki wyznaniowej jako elementu polityki publicznej, religia $\mathrm{w}$ wymiarze instytucjonalnym i systemowym, religia w kontekstach: międzynarodowym i geopolitycznym czy też zjawiska społeczne determinowane czynnikami religijnymi oraz zjawiska religijne determinowane czynnikami politycznymi.

W konferencji udział wzięli przedstawiciele szesnastu uczelni wyższych: Uniwersytetu Warszawskiego, Uniwersytetu Marii Curie-Skłodowskiej w Lublinie, Uniwersytetu Kardynała Stefana Wyszyńskiego w Warszawie, Uniwersytetu Mikołaja Kopernika w Toruniu, Uniwersytetu im. Adama Mickiewicza w Poznaniu, Uniwersytetu Zielonogórskiego, Uniwersytetu Wrocławskiego, Uniwersytetu Opolskiego, Uniwersytetu Łódzkiego, Uniwersytetu Ekonomicznego w Krakowie, Uniwersytetu Technologiczno-Humanistycznego w Radomiu, Akademii Ignatianum w Krakowie, Akademii Pomorskiej w Słupsku, Akademii im. Jakuba z Paradyża w Gorzowie Wlkp., Wyższej Szkoły Demokracji w Grudziądzu oraz Wojskowej Akademii Technicznej w Warszawie. Reprezentowane były również organizacje i stowarzysze- 
The three-day format of the session included seven plenary sessions, which closed the discussion each time. Referring both to theoretical issues and based on concrete expositions, papers presented the multithreaded nature of the analyzed area. The lectures concerned Poland during various periods, such as: Religious policy in the former Commonwealth (Prof. Dariusz Góra-Szopiński), Religion and politics. The Perspective of Polish Science on Politics The Specificity of IPS CSWU Workers (Prof. Janusz Węgrzecki), Place of Religion in Polish Reflection and Political Practice of the Beginning of the 21st Century (Prof. Michał Strzelecki) and Arguments Related to Religion in Political Debates in the Sejm (Prof. Krzysztof Łabędź).

Theoretical aspects were discussed in their speeches, including: Prof. Piotr Mazurkiewicz (discussing the theological justification of limited power), Dr. Anna Solarz (focusing on two research attitudes, called methodological atheism and methodological agnosticism), Dr. Dorota Maj (who referred to the issue of new religious movements as a form of social controversy), Dr. Andrzej Dwojnych (exploring issues of coherence and inconsistency in the relationship between nationalism and $\mathrm{Ca}$ tholicism), Dr. Marcin Pomarański (in the analysis of the phenomenon of the sacralization of political power), and Dr. Kamil Aksiuto (Religion and the public sphere in the political liberalism of John Rawls). nia, m.in.: Kongres Kobiet Konserwatywnych, Stowarzyszenie Europa Przyszłości, Towarzystwo Naukowe Płockie oraz Wydawnictwo „Agape”.

Trzydniowa formuła obrad obejmowała siedem sesji plenarnych, które każdorazowo zamykała dyskusja wokół poszczególnych wystąpień. Odnoszące się zarówno do kwestii teoretycznych, jak i oparte na konkretnych egzemplifikacjach referaty prezentowały wielowątkowość analizowanego obszaru. Wystąpienia odnosiły się do Polski w ciągu różnorodnych okresów, czego przykładami mogą być takie tematy jak: Polityka religijna na obszarze dawnej Rzeczypospolitej (prof. Dariusz Góra-Szopiński), Religia i polityka. Perspektywa polskich nauk o polityce - specyfika pracowników IP UKSW (ks. prof. Janusz Węgrzecki), Miejsce religii w polskiej refleksji i praktyce politycznej początków XXI wieku (prof. Michał Strzelecki) oraz Argumenty nawiazujace do religii w sporach politycznych w Sejmie (prof. Krzysztof Łabędź).

Aspekty teoretyczne poruszali w swoich przemówieniach m.in.: ks. prof. Piotr Mazurkiewicz (omawiający teologiczne uzasadnienie władzy ograniczonej), dr Anna Solarz (koncentrująca się na dwóch postawach badawczych, określanych mianem metodologicznego ateizmu oraz metodologicznego agnostycyzmu), dr Dorota Maj (która odniosła się do zagadnienia nowych ruchów religijnych jako formy kontestacji społecznej), dr Andrzej Dwojnych (zgłębiający kwestie spójności i niespójności w relacjach między nacjonalizmem a katolicyzmem), dr Marcin Pomarański (w analizie zjawiska sakralizacji władzy politycznej), a także 
The matters of religious and political interferences in international and geopolitical terms were the domain of speeches by Prof. Jaroslaw Macała (Geopolitics and religion), prof. Małgorzata Świder (Political aspects of the pilgrimages of John Paul II to Poland in the opinion of West German authorities), Kleopatra Kharof (Religion in international relations on the example of Turkey) and Dr. Piotr Pochyły (Axiological dimension of Polish foreign policy). In turn - for example - the paper by Łukasz Brodziak, MA, was referring to territorial micro-analysis (The meaning of the Church in local government and in local politics).

Numerous presentations can be classified as case studies. These included, among others the following topics: Uniate Churches of the Middle East: Vatican policy towards non-Christians (Prof. Michael Abdalla), Religion and politics in the Muslim fundamentalist writings published in Polish (Dr. Piotr Ślusarczyk), Muslim Brotherhood - future beneficiary of the Syrian conflict? The Maronite Church at the crossroads of religion and politics (Dr. Bartłomiej Grysa), Religious determinants of the golden age and the survival of the Assyrians as a nation without state (Prof. Mirosław Rucki), Massacre at Mountain Meadows: study of political efficiency (Dr. hab. Maciej Potz), Mobilization of evangelical voters in the US presidential election in 2016 (Dr. hab. Rafał Prostak), Protestant clergy in politics. Examples from the world (Prof. Paweł Leszczyński). dr Kamil Aksiuto (Religia a sfera publiczna w liberalizmie politycznym Johna Rawlsa).

Sprawy sprzężeń religii i polityki $\mathrm{w}$ wymiarze międzynarodowym i geopolitycznym były domeną wystąpień m.in: prof. Jarosława Macały (Geopolityka i religia), prof. Małgorzaty Świder (Polityczne aspekty pielgrzymek Jana Pawła II do Polski w ocenie władz zachodnioniemieckich), Kleopatry Kharof (Religia w stosunkach międzynarodowych na przykładzie Turcji) oraz dra Piotra Pochyłego (Aksjologiczny wymiar polskiej polityki zagranicznej). Z kolei - dla przykładu - referat mgra Łukasz Brodziaka odnosił się do terytorialnej mikroanalizy (Znaczenie Kościoła w samorzadzie i w polityce lokalnej).

Liczne wystąpienia sklasyfikować można jako casestudy. Obejmowały one m.in. następujące tematy: Unickie Kościoły Bliskiego Wschodu: polityka Watykanu wobec chrześcijan nierzymskich (prof. Michael Abdalla), Religia i polityka w pismach muzutmańskich fundamentalistów wydanych w języku polskim (dr Piotr Ślusarczyk), Bractwo Muzutmańskie - przyszły beneficjent konfliktu syryjskiego? (mgr Małgorzata Samojedny), Kościół maronicki na styku religii i polityki (dr Bartłomiej Grysa), Religijne uwarunkowania złotego wieku i przetrwania Asyryjczyków jako narodu bez państwa (prof. Mirosław Rucki), Masakra na Mountain Meadows: studium sprawczości politycznej (dr hab. Maciej Potz), Mobilizacja ewangelikalnego wyborcy $w$ amerykańskich wyborach prezydenckich $w 2016$ roku (dr hab. Rafał Prostak), Duchowni protestanccy w polityce. Przykłady ze świata (prof. Paweł Leszczyński). 
Yet another element of the conference was the breakdown of religious and political factors in Spain and Latin America. This issue was the keynote of presentations of Dr. Anna Ratke-Majewska, who discussed the relationship of liberation theology and socio-political reality in Latin America, and Wioleta Husar, MA, and Darla Podedworna, MA, analyzing the importance of religious factors in constructing Catalan national identity, Church in Spain during the rule of José Zapatero. Spanish subjects have also been discussed extensively in contextual analysis with regard to the challenges of secularization: Secularization and secularization - threats to modern Europe (Dr. Sylwia Górzna), The causes of crisis in the Catholic Church according to the Society of Pius X (Dr. Waldemar Rogowski), About liberal and conservative challenges for the public role of the Catholic Church (Dr. Michał Gierycz). The same secular motif, illustrated this time by example from Northern Europe, was also discussed by Martyna Masłowska, MA, (Swedish Church and the process of secularization of society in the context of the crisis of the welfare state).

Participants of the conference, with interest and satisfaction, also listened to the speeches of Natasza Dembińska-Urbaniak, MA, who argued about the utilitarian nature of political science of religion, which is reflected in reaching out to the findings of this sub-disciplines of political science by non-governmental organizations such as the Congress of Conservative Women.
Jeszcze innym elementem konferencji było wyszczególnienie kwestii przenikania się czynnika religijnego oraz politycznego na obszarach Hiszpanii i Ameryki Łacińskiej. Ta problematyka była przewodnią treścią wystąpień: dr Anny Ratke-Majewskiej, która omówiła kwestię relacji teologii wyzwolenia i rzeczywistości społeczno-politycznej w Ameryce Łacińskiej oraz mgr Wioletty Husar i mgr Darii Podedwornej, analizujących kolejno znaczenie czynnika religijnego w konstruowaniu katalońskiej tożsamości narodowej i stosunki państwo - Kościół w Hiszpanii w okresie rządów José Zapatero. Tematyka hiszpańska była również wydatnie omawiana w wystąpieniach zawierających analizę kontekstową w odniesieniu do wyzwań, jakie niesie sekularyzacja: Sekularyzacja i laicyzacja - zagrożenia dla wspótczesnej Europy (dr Sylwia Górzna), Przyczyny kryzysu w Kościele katolickim według Bractwa Piusa X (dr Waldemar Rogowski), O liberalnych $i$ konserwatywnych wyzwaniach dla publicznej roli Kościoła katolickiego (dr Michał Gierycz). Ten sam sekularyzacyjny motyw, ilustrowany tym razem przykładem z Europy Północnej, omówiła także mgr Martyna Masłowska (Kościót Szwecji a proces sekularyzacji społeczeństwa w kontekście kryzysu państwa dobrobytu).

Uczestnicy konferencji z zainteresowaniem i satysfakcją wysłuchali ponadto wystąpienia mgr Nataszy Dembińskiej-Urbaniak, która przekonywała o utylitarnym charakterze politologii religii, czego wyrazem jest sięganie do ustaleń tej subdyscypliny nauk o polityce przez organizacje pozarządowe, np. Kongres Kobiet Konserwatywnych. 
Altogether thirty-five papers were presented. Discussions during the session and in the lobby confirmed the need for cyclical meetings, exchange of views and confrontation of research results. Because of the real benefits for the scientific community, researchers in the political science of religion who came to Łagów agreed on the legitimacy of organizing conferences of the same profile, thus placing the University of Zielona Góra among the leading centers for the promotion of research in the political science of religion.
Łącznie wygłoszonych zostało trzydzieści pięć referatów. Podejmowane w trakcie obrad oraz w kuluarach dyskusje potwierdziły konieczność cyklicznych spotkań, wymiany poglądów oraz konfrontacji wyników badań. Ze względu na realne korzyści dla środowiska naukowego przybyli do Łagowa badacze politologii religii byli zgodni co do zasadności organizacji konferencji o tym samym profilu, zaliczając tym samym Uniwersytet Zielonogórski do grona czołowych ośrodków promocji badań nad politologią religii. 